\title{
Management of Inguinal Hernia in Pediatric Age Group
}

\author{
Muataz Alani, Nehad kasim, Saad Abdulrazak \& Mohammed Abdulkareem Oleiwi \\ Al-khansaa teaching hospital, Nineveh Health Department, Mosul, Iraq.
}

\section{Drmoutazalani@yahoo.com}

\begin{abstract}
Introduction: Incidence of indirect inguinal hernias in premature infants is reported to be as high as $30 \%$ with male predominance. Typically, inguinal hernia repairs are done under general anesthesia which has a high risk of post-operative complications, especially in the premature infant. The purpose of this study was to compare outcomes between early (neonatal) and delayed (older) inguinal hernia repair.

Method: This is a prospective study in the department of pediatric surgery in alkhansaa Teaching Hospital Mosul / Iraq during a period from Jul 2018 to Dec 2019. All children with inguinal hernia were selected for the study and divided in two groups, those below one month and those above. Surgery is performed under general anesthesia with extracanalicular approach. Post-operative complications were observed and finally decided to discharge once patient is fit for discharge on the same day.

Results: During the 18 months' period, we underwent 93 inguinal hernia repair those babies were divided into two groups, neonatal group (23 neonates) and older group (70 babies). The gender distribution ratio is 7.8 male $: 1$ female. The side distribution among those babies in the neonatal group were 14,6 and 3 as right, left and bilateral respectively. In the neonatal group there were 9 babies presented with incarceration two $(8.6 \%)$ of them shows testicular infarction and necrosis which necessitate excision at exploration while the other one atrophied in the period of follow up. We do not record any anesthetic complications or mortality in neonatal group in our period of study.
\end{abstract}


Conclusion: Extracanalicular approach under general anesthesia is easy, safe, can be used for pediatric patients in neonatal age group with indirect inguinal hernia; with minimal complications, low recurrence rate.

Key words: Inguinal Hernia, neonates.

الخلاصة

مقدمة: تثبير التقارير إلى أن نسبة حدوث الفتق الإربي غير المباثر عند الخدج تصل إلى 30٪ مع هيمنة الذكور.

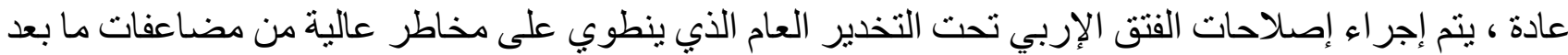
الجر احة ، خاصة عند الأطفال الخذج. كان الغرض من هذه الدراسة هو مقارنة النتائج بين إصلاح الفتق الإربي

$$
\text { المبكر (حديث الولادة) و المتأخر (بعد عمر } 28 \text { يوما). }
$$

الطريقة: هذه در اسة مستقلية في قسم جر احة الأطفال في مستشفى الخنساء التعليمي الموصل / العر اق خلال الفترة من يوليو 2018 إلى ديسمبر 2019. تم اختيار جميع الأطفال الذين يعانون من الفتق الإربي للار اسة وتم تقسيمهم إلى مجموعتين ، أولئك الذين تقل أعمار هم عن شهر و احد و الذين اعمار هم اكبر من 28 يو ما. يتم إجر اء الجراحة تحت التخدير العام باختيار طريقة خارج القناة الاربية. لوحظت مضاعفات ما بعد الجراحة في كلتا المجمو عتنين ومغادرة الطفل للمستشفى بمجرد أن يكون المريض صالحًا للمغادرة في نفس اليوم. النتائج: خلال فترة 18 شهرًا ، اجرين اتداخل جر احي لـ 93 فتقًا أربيًا تم تقسيم هؤلاء الأطفال إلى مجمو عتين ، مجمو عة حديثي الو لادة (23 حديثي الو لادة) ومجموعة أكبر سنًا (70 رضيعًا). نسبة التوزيع بين الجنسين 7.8 ذكر: 1 أنثى. كان التوزيع الجانبي بين هؤلاء الأطفال في مجموعة الأطفال حديثي الو لادة 6،14, 3 في اليمين و اليسار والثنائي على التو الي. في الجمو عة حديثي الو لادة ، كان هناك 9 أطفال مصابين باختناق الفتق الاربي اثثين (8.6\%) منهم يظهر احتشاء الخصيتين بينما يعاني الآخر من ضمور للخصية في فترة المتابعة. لم يتم زسجل أي مضاعفات تخديرية أو وفيات في مجموعة حديثي الو لادة في فترة در استنا. الخلاصة: ان اختيار طريقة خارج القناة الاربية لتصحيح الفتق الاربي في حديثي الولادة تحت التخدير العام سهل و آمن ويمكن استخدامه لمرضى الأطفال في المجمو عة العمرية حديثي الولادة الذين يعانون من الفتق الإربي غير الفير المباثر ؛ مع الحد الأدنى من المضاعفات.

الكلمات المفتاحية: الفتق الأربي ، الخدج ،مضاعفات. 


\section{Introduction}

工 $\begin{aligned} & \text { ernia means a "protrusion of a } \\ & \text { viscus or part of a viscus }\end{aligned}$ through a normal or an abnormal opening in the wall of its containing cavity." (1) As a result of improved neonatal intensive care, more and more premature babies are being delivered and consequently the incidence of neonatal inguinal hernia is increasing.

Incidence of inguinal hernias in premature infants is reported to be as high as $30 \%$ with male predominance ${ }^{(2-}$ 4). Frequency of inguinal hernia is inversely related to birth weight with rates highest in less than $1000 \mathrm{~g}$ population ${ }^{(5)}$. The risk of incarceration is doubled in premature neonates with inguinal hernia when repair is delayed ${ }^{(2)}$. Approximately half of these low birthweight infants are found to have bilateral hernias.

All pediatric inguinal hernias require operative treatment to prevent the development of complications, such as inguinal hernia incarceration or strangulation. Only $63 \%$ of pediatric surgeons report routinely repairing inguinal hernia before infants are discharged from the hospital. Delaying repair increases the likelihood of a recurrence of incarceration to $31 \%$, compared to only $5 \%$ if repaired during the initial hospitalization. Typically inguinal hernia repairs are done under general anesthesia which has a high risk of post-operative complications, especially in the premature infant. Complication rate is as high as $12 \%$ and includes apnea, bradycardia ${ }^{(6)}$.

The purpose of this study was to examine practice variability and compare outcomes between early (neonatal) and delayed (older) inguinal hernia repair.

\section{Method}

This is a prospective case series study in the department of pediatric surgery in Central Child's Teaching Hospital ( Mosul) during the period from Jul 2018 to Dec 2019.

All children age ranged from 1 day to 12 years with inguinal hernia who attended Pediatric surgical unit were selected for the study and divided in two groups, 
those below one month as a neonatal group and those above as older age group. Congenital inguinal hernia was diagnosed by taking detailed history from parents in the form of site, size, variability of size, history of nonreducibility. After obtaining the history babies were examined systematically. Babies were subjected to routine investigations include $\mathrm{Hb} \%$, hepatitis screen and chest $\mathrm{x}$-ray and ultrasound examination.

After proper evaluation of preoperative condition and appropriate preparation, surgery is considered at a fixed appointment within one week. Surgery is performed under GA with lower transverse abdominal skin crease incision, high ligation of the sac at extracanalicular approach.
Postoperatively babies were monitored to exclude any complications and finally decided to discharge-once patient is fit for discharge- on the same day. All patients were asked for follow-up in a one-month period postoperatively.

\section{Results}

During the 18 months period, the surgical team had been managed 93 inguinal hernia at pediatric surgical department, those babies were divided into two groups, neonatal group (23 neonates) and older group (70 babies). Regarding those in the neonatal group all of them had been waited to complete the gestational age of 38-40 weeks and we don't have any premature babies in our study The age distribution is seen in the fig. (1): 


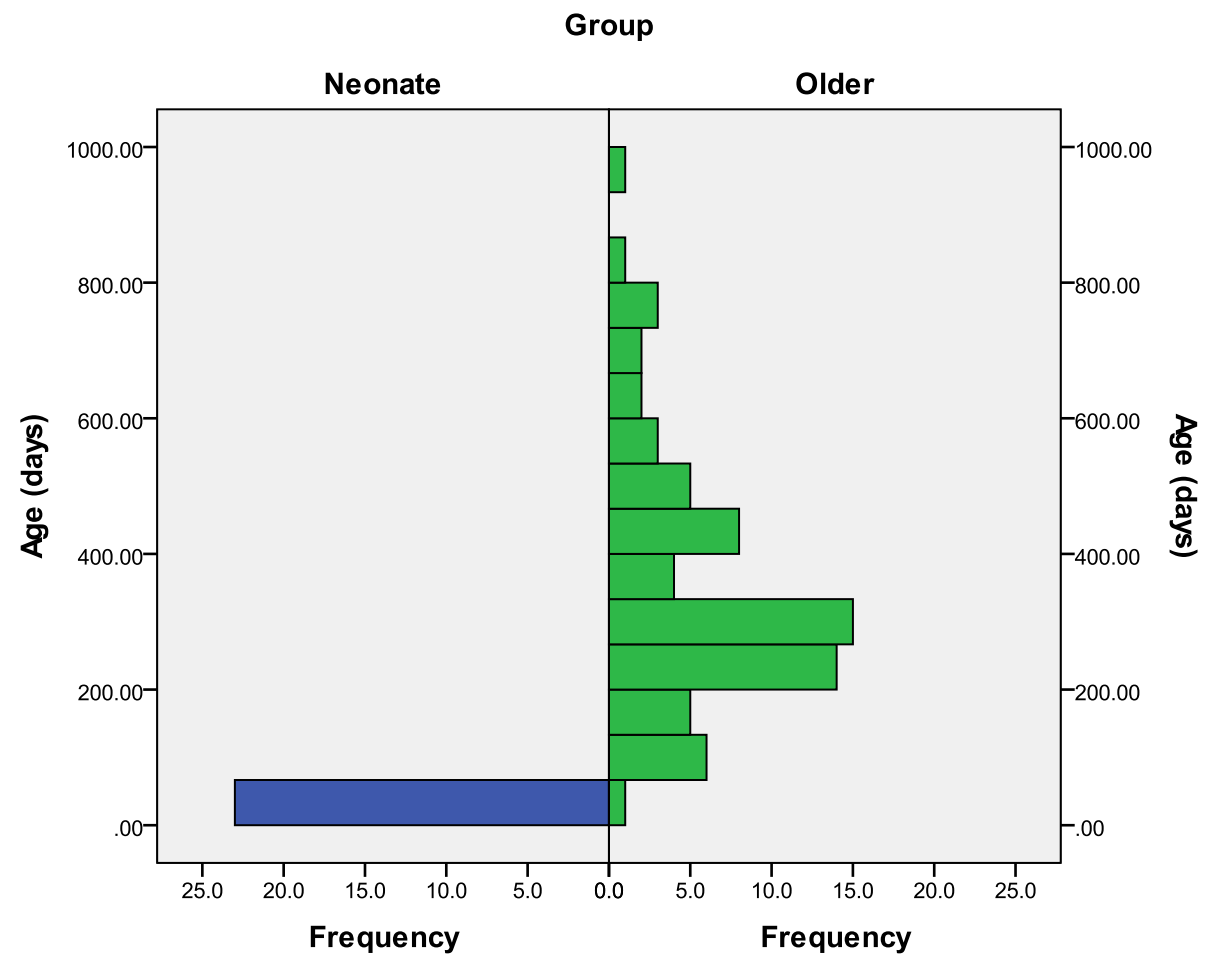

Figure (1): Age Distribution

In the neonatal group (23) there were 18 males and 5 females, a ratio of 3.5:1, while the gender distribution in the older group is 8 females and 62 males, the ratio being 7.8:1. the Side Distribution among those babies in the neonatal group were 14, 6 and 3 as right, left and bilateral respectively, while at the older group the side distribution were 49,15 and 6 as right, left and bilateral respectively as shown in table 1 . 
Table 1: Groups of patients ( Neonate \& older) site of hernia.

\begin{tabular}{|cc|c|c|c|c|c|c|}
\hline \multirow{2}{*}{} & \multicolumn{3}{|c|}{ Site of Hernia } \\
\cline { 3 - 8 } & & \multicolumn{2}{|c|}{ Right } & \multicolumn{2}{c|}{ Left } & \multicolumn{2}{c|}{ Bilateral } \\
\cline { 3 - 8 } & & Count & $\begin{array}{c}\text { Column N } \\
\%\end{array}$ & Count & Column N \% & Count & Column N \% \\
\hline \multirow{2}{*}{ Group Neonate } & Male & $\mathbf{1 4}$ & $\mathbf{1 0 0 . 0}$ & $\mathbf{4}$ & 66.7 & $\mathbf{0}$ & .0 \\
& Female & $\mathbf{0}$ & .0 & $\mathbf{2}$ & 33.3 & $\mathbf{3}$ & $\mathbf{1 0 0 . 0}$ \\
& Male & $\mathbf{4 1}$ & 83.7 & $\mathbf{1 5}$ & $\mathbf{1 0 0 . 0}$ & $\mathbf{6}$ & $\mathbf{1 0 0 . 0}$ \\
& Female & $\mathbf{8}$ & 16.3 & $\mathbf{0}$ & .0 & $\mathbf{0}$ & .0 \\
\hline
\end{tabular}

The diagnosis of the inguinal hernia depend on the observation of the family and the examination of the specialized surgeon, there were nine babies (39.1\%) presented with incarcerated hernia in the neonatal group all of them were males, while in the older group there were 14 babies (20\%) presented with incarceration, eight of them were female. Strangulation of the contents with testicular necrosis were observed in three babies $(4.2 \%)$ in the older group at the time of exploration which necessitate removal of the necrotic tissues. While in the neonatal group there were 9 babies presented with incarceration, two $(8.6 \%)$ of them showed testicular infarction and necrosis which necessitate excision at exploration while the other one atrophied in the period of follow up. Fig. (2).

We did not record any anesthetic complications or mortality in our period of study. 


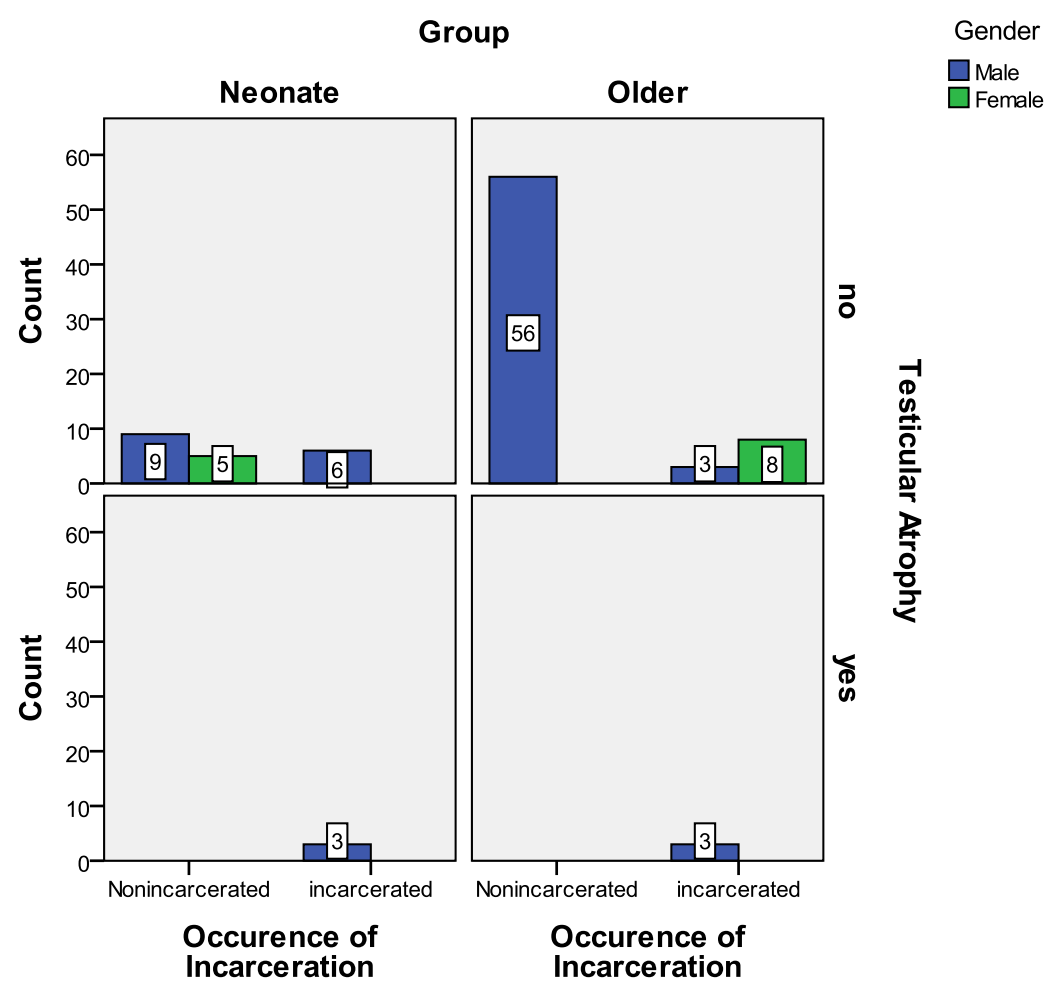

Figure (2): Distribution of patients regarding, gender, group, incarceration and testicular atrophy.

\section{Discussion}

Inguinal hernia is a common condition requiring surgical repair in the pediatric age group. The incidence of inguinal hernias is approximately $3 \%$ to $5 \%$ in term infants and $30 \%$ in infants born at less than 33 weeks of gestational age. ${ }^{(7)}$

The clinical diagnosis of inguinal hernia depends on the physical examination. It is recommended that the surgeon should not depend solely on the history but confirms the presence of a hernia himself. In this study all the cases were confirmed by physical examination, Generally, the younger the child, the more urgent the operation is, because of the increased risk of incarceration.

Many investigators have defined the risk of inguinal hernia incarceration in young children. However, the clinical finding of hernia, such as, the amount of the herniating intestine, and the ease 
with which it can be reduced, do not give a hint about the risk of incarceration.

Attempts have been made to correlate the age at diagnosis, the duration between diagnosis and hernia repair, and infants' gestational age with risk of inguinal hernia incarceration. Notably, in an analysis of a Canadian administrative database containing more than 1000 children with inguinal hernia, Zamakshary et al showed that children younger than 1 year had a twofold greater risk of inguinal hernia incarceration when repair was performed $\geq 14$ days after diagnosis compared with children who had repair performed between 1 and 2 years of age. ${ }^{(8)}$

Regarding the gender distribution in our study, 80 children were males and 13 children were females, thus making a male to female ratio of 6.1:1. (Neonatal group is 3.5 male: 1 female, while in the older group is 7.8:1), In other studies, male to female ratio ranged from $7: 1$ to 11.5:1. It was reported as $7: 1$ by ${\text { Grossfeld et } \mathrm{al}^{(7)}, 6: 1 \text { by Poenarau }}^{(9)}, 9: 1$ by Ravikumar et $\mathrm{al}^{(10)}$, this difference may be attributed to the behavior in our locality for the male baby as they are overprotected from surgical consultation Table 2.

Table 2: Percentage of gender between neonate $\&$ older patients.

\begin{tabular}{|c|c|c|c|c|c|}
\hline & \multicolumn{4}{|c|}{ Group } \\
\hline & & \multicolumn{2}{|c|}{ Neonate } & \multicolumn{2}{|c|}{ Older } \\
\hline & & Count & $\begin{array}{c}\text { Column N } \\
\%\end{array}$ & Count & $\begin{array}{c}\text { Column N } \\
\%\end{array}$ \\
\hline \multirow[t]{2}{*}{ Gender } & Male & 18 & 78.3 & 62 & 88.6 \\
\hline & Female & 5 & 21.7 & 8 & 11.4 \\
\hline
\end{tabular}

In this study, we found a higher incidence of inguinal hernia on right side $63(67.7 \%) .21$ (22.5\%) hernia were left sided and 9 (9.7\%) were bilateral. Our observations matched with the observations of Ravikumar et $\mathrm{al}^{(10)}$, who 
have reported an incidence of $64 \%$ and $56 \%$ for right sided inguinal hernia in their studies, respectively. Similarly, Rowe et $\mathrm{al}^{(11)}$ and Grossfeld et $\mathrm{al}^{(7)}$ have also reported a higher incidence of inguinal hernia on right side as shown in Table 3.

Table 3: Site of hernia.

\begin{tabular}{|c|c|c|c|c|c|}
\hline & \multicolumn{4}{|c|}{ Group } \\
\hline & & \multicolumn{2}{|c|}{ Neonate } & \multicolumn{2}{|c|}{ Older } \\
\hline & & Count & Column N \% & Count & Column N \% \\
\hline \multirow[t]{3}{*}{ Site of Hernia } & Right & 14 & 60.9 & 49 & 70.0 \\
\hline & Left & 6 & 26.1 & 15 & 21.4 \\
\hline & Bilateral & 3 & 13.0 & 6 & 8.6 \\
\hline
\end{tabular}

The fact that inguinal hernias are not self-limiting and that there is a risk of complications dictates the need for expedient surgical repair. ${ }^{(12)}$ Parental anxiety while waiting for surgery is another important issue. In a survey by Miller of parents of children awaiting various operations, $49 \%$ of the children were waiting for repair of an inguinal hernia. Over $95 \%$ of the families in the survey suggested that the wait for surgery was emotionally stressful. Furthermore, $37 \%$ felt that waiting for surgery prohibited them from participating in their usual activities. ${ }^{(13)}$
Recent inguinal hernia guidelines recommended that the operations can be carried out in daycare except in the neonatal age group and that the use of local anesthesia should be considered more often which is our usual work. If an incarcerated hernia cannot be reduced, emergency operation is necessary and referral to a pediatric surgical centre must be considered.

A recent meta-analysis concluded that former preterm infants undergoing general anesthesia who are less than 46 weeks' corrected gestational age should be observed for at least 12 hours postoperatively and that those who are 
between 46 and 60 weeks' corrected gestational age should receive more individualized care on the basis of the presence or absence of associated comorbidities. ${ }^{(14)}$

Early elective inguinal hernia repair is recommended for newborns and infants hospitalized for complications of the concurrent disease, before discharge from the ward. Older children with an uncomplicated perinatal history can be operated on safely as outpatients ${ }^{(15)}$. Nine $(33 \%)$ out of 23 babies in the neonatal group were presented with incarceration and had been operated on once stabilized. At exploration, three babies had sever affection of the blood supply of the testes ends with the necrosis which is unavoidable complication following incarceration unless there is early diagnosis and intervention especially in neonatal age group. In older children with an asymptomatic inguinal hernia, but aged less than 1 year, surgery should not be left to exceed 14 days after initial diagnosis, as the risk of incarceration is twofold greater than children with inguinal hernia and aged 1-2 years ${ }^{(16)}$.
Twenty-two percent in the older group presented with incarceration all of them operated upon at the same hospitalization.

We don't recommend or use spinal anesthesia in our daily practice following Craven et al. ${ }^{(17)}$ who shows that in his meta-analysis of Cochrane Collaboration of 4 studies, there was no evidence that spinal anesthesia is superior to general anesthesia in terms of postoperative apnea, bradycardia or oxygen desaturation. Caudal anesthesia has been commonly used in pediatric patients as an adjunct to general anesthesia and as an efficient agent for postoperative pain relief ${ }^{(18)}$.

During the period of $1 \& 1 / 2$ years study and follow-up period of 4 weeks, $1(0.9 \%)$ case had recurrence in baby with incarceration in neonatal age group. Recurrent inguinal hernias are relatively uncommon. Reports from most children's document an incidence of $1 \%$ to $2 \%$. The recurrence may be associated with co-morbid conditions including increased abdominal pressure, prematurity, malnutrition, and anemia and connective tissue disorders. Other 
causes of recurrence include a missed sac and injury to the floor of the inguinal canal resulting in a direct hernia. Recurrence is also seen more frequently after an initial operation for incarcerated hernia like in our baby. The hernia recurrence rate of $0.9 \%$ in our series is less than the reported range of 2.6-8.6\%. Vaos et al., ${ }^{(18)}$ had reported a hernia recurrence rate of $12.1 \%$. They suggested that repair of incarcerated inguinal hernia is associated with a high likelihood of recurrence because of technical difficulties from edematous and friable sac. The repair of a child's hernia is not a parlor piece, but a master's work and should be preformed or supervised by a skilled surgeon.

\section{References:}

1. Eubanks S: Hernias in Sabiston Text Book of Surgery; Sabiston D.C. Jr. and Lyerly H.k. 1999 15th Ed, Vol. I, 1215- 1217.

2. Lautz TB, Raval MV, Reynolds M Does timing matter? A national perspective on the risk of incarceration in premature neonates with inguinal hernia. $\mathrm{J}$ Pediatr . 2011; 158(4): 573-577.

3. Burgmeier C, Dreyhaupt J, Schier F Gender-related differences of inguinal hernia and asymptomatic patent processus vaginalis in term and preterm infants. $\mathrm{J}$ Pediatr Surg . 2015; 50(3): 478-480.

4. Skoog SJ, Conlin MJ Pediatric hernias and hydroceles. The urologist's perspective. Urol Clin North Am. 1995; 22(1): 119-130.

5. Harper RG, Garcia A, Sia C Inguinal hernia: a common problem of premature infants weighing 1,000 grams or less at birth. Pediatrics: 1975;56(1): 112115.

6. Somri M, Gaitini L, Vaida S, Collins G, Sabo E, et al. Postoperative outcome in highrisk infants undergoing herniorrhaphy: comparison between spinal and general anaesthesia. Anaesthesia . 1998;53(8): 762- 766.

7. Grosfeld JL. Current concepts in inguinal hernia in infants and 
children. World

JSurg. 1989;13(5):506- 515.

8. Zamakhshary M, To T, Guan J, L anger JC. Risk of incarceration of inguinal hernia among infants and young children awaiting elective surgery. CMAJ. 2008;179(10):10 01-1005.

9. Dan Poenaru, Inguinal hernias and hydroceles in infancy and childhood: A consensus statement of the Canadian Association of Paediatric Surgeons : Paed Child health.2000; Nov-Dec; 5(8): 461462. 8

10.V.Ravikumar, Rajshankar S, Hareesh R.S.Kumar, Nagendra Gowda M.R.: A clinical study of the management of inguinal hernias in children on the general surgical practice, Journal of Clinical and Diagnostic Research. 2013; Vol-7:(1), 144-147

11. Rowe MI, Lloyd DA et al., Inguinal Hernia in Pediatric Surgery. Year Book Medical Publishers. 4th edn. 1968.
12. Borenstein $S H$, To $T$, Wajja A, et al. Effect of subspecialty training and volume on outcome after pediatric inguinal hernia repair. $J$ Pediatr Surg 2005;40:75-80.

13.Miller GG. Waiting for an operation: parents' perspectives. Can $J$ Surg 2004;47:179-81.

14. Walther-

Larsen S, Rasmussen LS. The former preterm infant and risk of post-operative apnoea: recommendations for management. Acta Anaesthesiol Scand. 2006;50(7):888893pmid:16879474

15.Morse, T.S. Pediatric Outpatient Surgery. Journal of Pediatric Surgery.1972; 7: 283-286.

16.Zamakhsary, M., To, T., Guan, J. and Langer, J.C. () Risk of Incarceration of Inguinal Hernia among Infants and Young Children Waiting Elective Surgery. Canadian Medical Association Journal. 2008;179: 1001-1005. 
17.Craven, P.D., Badawi, N.,

Hederson-Smart, D.J. and

O’Brien, M. (2003) Regional

(Spinal, Epidural, Caudal) versus

General Anesthesia in Preterm

Infants Undergoing Inguinal

Herrniorrhaphy in Early Preterm

Infancy. Cochrane Database of
Systematic Reviews, 3, Article ID: CD003669.

18. Vogels HD, Bruijnen CJ, Beasley SW. Predictors of recurrence after inguinal herniotomy in boys. Pediatr Surg Int. 2009;25:235-8. 